\title{
Editorial
}

\section{Terapia Ocupacional: validação, emancipação do campo profissional e exercício de cidadania}

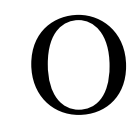

intenso conflito aberto pela luta de profissionais de Fisioterapia e Terapia

Ocupacional em defesa do direito de realizar eleições livres para a direção do

Conselho Regional de Fisioterapia e Terapia Ocupacional - CREFITO 3 - fez emergir um conjunto de questões importantíssimas que afeta a todos os profissionais dessas áreas e tornou claro o quanto estamos e estivemos mal representados pelo órgão que deveria zelar pelo exercício das profissões de Fisioterapia e Terapia Ocupacional e defender seus lugares e papéis sociais. Ao invés nos parece que o sistema COFFITO-CREFITO se viu transformado num espaço marcado pela improbidade administrativa, falta de democracia interna e total distanciamento dos interesses dos profissionais, funcionando como um órgão que capta recursos de forma compulsória dos profissionais e os administra de forma obscura.

Nesse contexto cabe aos terapeutas ocupacionais refletirmos sobre aquilo que nos é tão caro nos processos de reabilitação psicossocial das populações por nós assistidas, o resgate dos direitos de cidadania e do protagonismo social.

Nós também, enquanto profissionais e cidadãos precisamos resgatar nossos direitos e poder protagonizar processos que articulem exercício profissional e ética, para que continuemos ampliando nossa validação enquanto profissionais comprometidos com o direito da população às Políticas Públicas necessárias para a constituição do Estado de Direito e da atenuação das extremas desigualdades presentes em nossa sociedade. Nos constituímos como uma categoria profissão ainda pequena, em termos de número de profissionais, quando comparadas às demais profissões da saúde e vimos enfrentando as crescentes dificuldades de inserção no mercado de trabalho, aliada ao rebaixamento salarial e ao aumento da pressão por produtividade, resolutividade e eficácia das práticas empreendidas. $\mathrm{O}$ aumento sem critérios do número de cursos de graduação não se vê acompanhado do necessário empenho para criação de postos de trabalho para os futuros jovens profissionais, nem da significativa ampliação das políticas sociais voltadas para as populações vulneráveis.

O enfrentamento desse contexto crítico requer o associativismo dos profissionais e a efetivação de órgãos de representação capazes de proporem respostas criativas e adequadas aos problemas atuais.

Esperamos que a luta pela democratização do sistema COFFITO-CREFITO seja vitoriosa, mas sabemos que resolvido esse embate terá início o verdadeiro embate e dele terão que fazer parte muitos profissionais dispostos a contribuírem na invenção do futuro da nossa profissão.

\author{
Elisabete Ferreira Mângia \\ Marta Carvalho de Almeida \\ Docentes do Departamento de Fisioterapia, \\ Fonoaudiologia e Terapia Ocupacional da \\ Faculdade de Medicina da USP e editoras \\ da Revista de Terapia Ocupacional da USP.
}

